\title{
Complete genome sequence of acute viral necrosis virus associated with massive mortality outbreaks in the Chinese scallop, Chlamys farreri
}

\author{
Weicheng Ren ${ }^{1,2}$, Haixia Chen ${ }^{3}$, Tristan Renault ${ }^{4}$, Yuyong Cai ${ }^{1}$, Changming Bai ${ }^{1}$, Chongming Wang ${ }^{1 *}$ \\ and Jie Huang ${ }^{1}$
}

\begin{abstract}
Background: Acute viral necrosis virus (AVNV) is the causative agent of a serious disease resulting in high mortality in cultured Chinese scallops, Chlamys farreri. We have sequenced and analyzed the complete genome of AVNV.

Results: The AVNV genome is a linear, double-stranded DNA molecule of 210,993 bp with a nucleotide composition of $38.5 \% \mathrm{G}+\mathrm{C}$. A total of 123 open reading frames were predicted to encode functional proteins, ranging from 41 to 1,878 amino acid residues. The DNA sequence of AVNV is 97\% identical to that of ostreid herpesvirus 1 (OsHV-1), and the amino acid sequences of the encoded proteins of these two viruses are 94-100\% identical. The genomic organization of AVNV is similar to that of OsHV-1, and consists of two unique regions (170.4 kb and $3.4 \mathrm{~kb}$, respectively), each flanked by two inverted repeats (7.6 kb and $10.2 \mathrm{~kb}$, respectively), with a third unique region $(1.5 \mathrm{~kb})$ situated between the two internal repeats.
\end{abstract}

Conclusions: Our results indicate that AVNV is a variant of OsHV-1. The AVNV genome sequence provides information useful for understanding the evolution and divergence of OsHV-1 in marine molluscs.

Keywords: Acute viral necrosis virus (AVNV), Herpesvirus, OsHV-1, Genome

\section{Background}

Although viral infection in marine molluscs is a relatively young science, pathogens of this type have been reported worldwide in association with massive mortality outbreaks in economically significant species. Massive mortality of Portuguese oysters, Crassostrea angulata, in French stocks from 1967 to 1973 was associated with irido-like virus infections [1,2]. Other viruses infecting molluscs were interpreted as being members of the families Togaviridae, Retroviridae, Reoviridae, Birnaviridae or Picornaviridae [3-9]. Disseminated neoplasia, which was a proliferative cell disorder of the circulatory system in bivalves, was linked to the retroviral infections [10]. However, mollusc virology is still in its infancy and is based largely on morphological features because relevant biological and molecular tools are scarce.

\footnotetext{
*Correspondence: wangcm@ysfri.ac.cn

${ }^{1}$ Maricultural Organism Disease Control and Pathogenic Molecular Biology Laboratory, Yellow Sea Fisheries Research Institute, Chinese Academy of Fishery Science, Qingdao 266071, China

Full list of author information is available at the end of the article
}

Herpesviruses comprise an abundant, widely distributed group of large DNA viruses in vertebrates and invertebrates, including mammals, birds, reptiles, fish and marine molluscs. They were classified into the families Alloherpesviridae, Herpesviridae and Malacoherpesviridae in the order Herpesvirales [11]. The genomes of herpesvirus have been accumulating since the 1980s, and sixtyeight isolated from different species have been deposited in GenBank to date. These genomes have been interpreted to give detailed views of ubiquitous and lineage-specific functions. Herpesviruses and herpes-like viruses have also been attracted particular attention because of their ecological and economic impact on wild and cultured marine molluscs during the last 20 years, and several were reported worldwide [12-27]. The term herpes-like virus tends to be used when a virus has been characterized exclusively on the basis of morphological features. One herpesvirus that infects Pacific oysters, Crassostrea gigas, in France, has been fully characterized on both morphological and molecular basis. This virus was named 
ostreid herpesvirus 1 and was classified as the founding member of the species Ostreid herpesvirus 1, genus Ostreavirus, family Malacoherpesviridae [11,25]. Although OsHV-1 was first described in the larvae of Pacific oysters in France, further studies have demonstrated that it was able to infect other bivalve species, including Manila clam, Ruditapes philippinarum [27], and French scallop, Pecten maximus [28]. Recently, a distinct OsHV-1 genotype (OsHV-1 $\mu \mathrm{Var})$ has been also reported in association with massive mortality in Pacific oysters in France [29].

Since the mid-1990s, the farming of Chinese scallops has experienced a period of severe crisis due to the ongoing mortality outbreaks. The disease has occurred annually in summer and mortality reaches more than 90\% within 5-8 days after first appearance [30,31]. The causative agent was determined to be a virus and was named acute viral necrosis virus (AVNV) [32,33]. According to the previous data, AVNV seems to be related to OsHV-1 based on morphology [33,34], histopathological features such as basophilic inclusions and cellular changes [34,35], and epidemiological aspects [36]. Therefore, based on the published OsHV-1 DNA sequences as a template, we have sequenced the complete genome of AVNV and have carried out the comparative analysis.

\section{Results}

\section{Determination of the AVNV genome sequence}

Because no reliable cell lines are available for the propagation and isolation of AVNV, a PCR-based approach was used to obtain the complete genomic DNA sequences. Initially, OsHV-1 specific primers A3/A4 [26], C2/C6 [28] and Gp3/Gp4 [28] were used to amplify AVNV DNA sequences, which were then compared to the corresponding OsHV-1 sequences. The results showed that these three AVNV fragments were 99\%, 97\% and 99\% identical to OsHV-1, respectively (data not shown), thus indicating that the DNA sequences of these two viruses may be generally highly similar. We then extended the PCR-based method to sequence the whole genome of AVNV by designing primers based on the OsHV-1 DNA sequences.

The AVNV genome was initially determined to be 210,825 bp in size. However, a large palindrome located correspondingly between ORF49 and ORF50 in the OsHV-1 genome appeared to be deleted upon cloning into the plasmids used for sequencing [25]. Palindromes that are deleted in similar circumstances were also reported in members of the subfamily Alphaherpesvirinae $[37,38]$ and in the genus Roseolovirus of the subfamily Betaherpesvirinae [39]. We resolved the sequence of this region in AVNV by using the method described by Weller et al. [38]. Finally, the complete AVNV genomic DNA sequences was determined to be $210,993 \mathrm{bp}$, and had a nucleotide composition of $38.5 \% \mathrm{G}+\mathrm{C}$. The structure of the AVNV genome consisted of two unique regions (170.4 $\mathrm{kb}$ and $3.4 \mathrm{~kb}$, respectively), each flanked by an inverted repeat (7.6 and $10.2 \mathrm{~kb}$, respectively), with the internal copies of the repeats separated by a third unique $1.5 \mathrm{~kb}$ region (Figure 1).

\section{Coding capacity of the AVNV genome}

Analysis of the AVNV genome resulted in the prediction of 123 unique open reading frames (ORFs) potentially encoding functional proteins and ranging in size from 41 to 1,878 amino acid residues (Additional file 1: Table $\mathrm{S} 1$ ). Owing to the presence of the inverted repeats, 12 ORFs were duplicated, resulting in a total of 135 putative genes in AVNV. The ORFs on the upper (R) and lower (L) DNA strands (53\% lower, 47\% upper) were numbered following the OsHV-1 nomenclature (Additional file 1: Table S1) and a diagrammatic representation of their arrangement was shown in Figure 1. The proportion of the genome encoding ORFs was about $82 \%$, which was similar to that of OsHV-1 (84\%). The average length of AVNV ORFs was $1,260 \mathrm{bp}$, which was marginally smaller than that of OsHV-1 (1,272 bp). Five pairs of overlapping ORFs were found in the AVNV genome, including ORF56 and ORF57, ORF71 and ORF72, ORF81 and ORF82, ORF92 and ORF93, and ORF94 and ORF95 (Figure 1), with the overlapping regions being 8-251 bp in size. ORF28 and ORF29 overlapped by $125 \mathrm{bp}$ in OsHV-1 [25] but are present as a single ORF 28 in AVNV (Additional file 1: Table S1).

\section{Overall comparisons between the AVNV and OsHV-1 genomes}

OsHV-1 was classified as the founding member of the family Malacoherpesviridae [11], which differs significantly from other herpesvirus families [40]. Therefore, we compared the genome sequence of AVNV with that of OsHV-1. The results showed that AVNV was similar to OsHV-1 in genome organization, DNA sequences and ORF layout (Figure 1). The majority of AVNV ORFs were closely matched in size and orientation with their OsHV-1 counterparts, with identities from $94 \%$ to $100 \%$ (Additional file 1: Table S1). The AVNV and OsHV-1 DNA sequences were also very similar, exhibiting about 97\% identity overall. However, there were several obvious insertions and deletions between the two genomes, the most notable being located in the AVNV genome at positions $1,500-1,700,60,700-63,350,183,900-184,100$, 187,300-190,300, 192,800-195,100, 203,000-205,100 and 207,800-210,700. All of these above variations were located in the non-coding regions. 

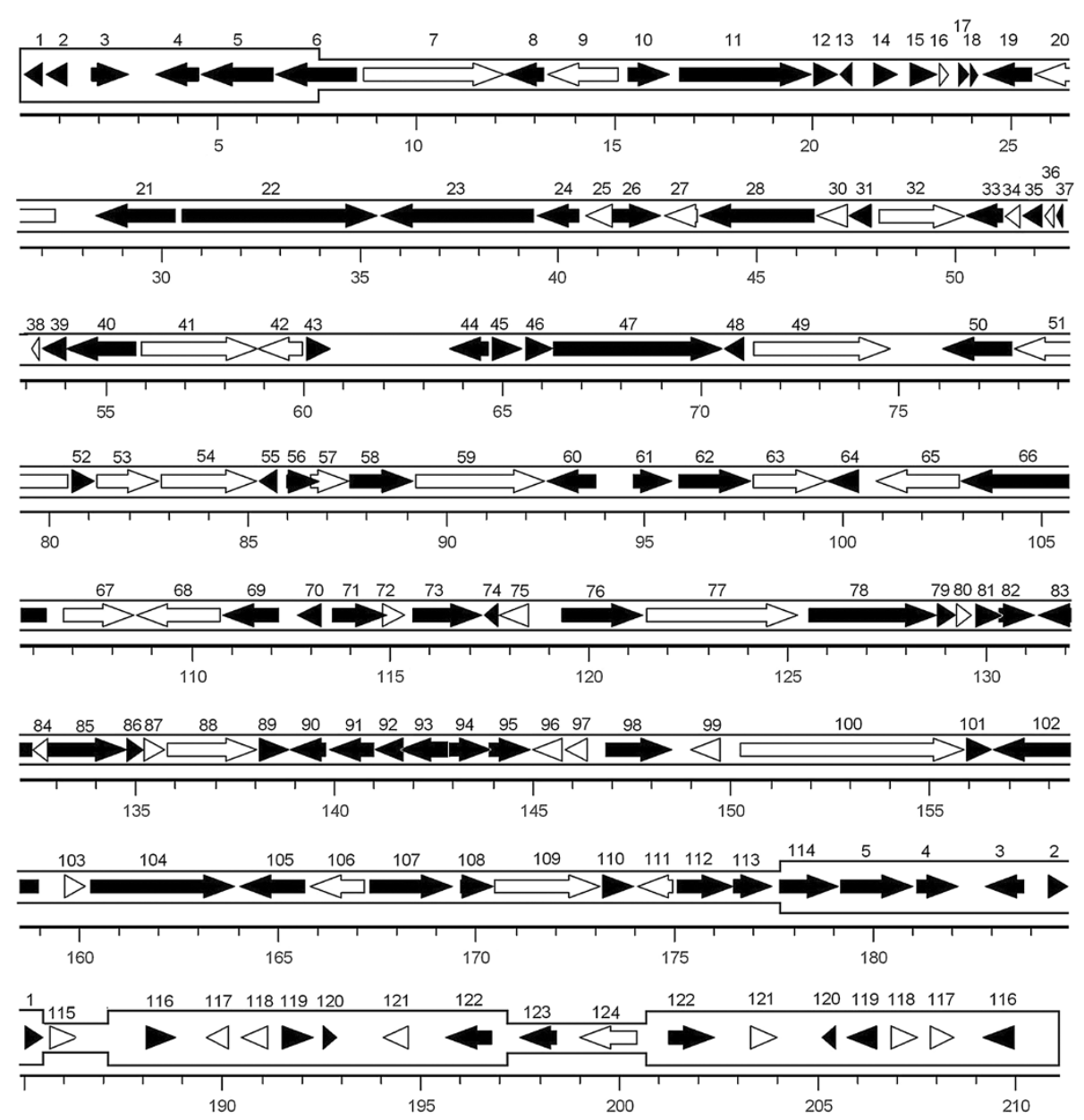

Figure 1 Organization of the AVNV genome. Arrows indicate the location and orientation of the ORFs. White arrows represent ORFs with predicted functions similar to those in other herpesviruses, and black arrows represent ORFs with unknown functions. The two inverted repeats (ORF1-ORF6 and ORF116-ORF122) are shown in a thicker format. The scale is in kb.

\section{Comparisons of $\mathrm{C} 2 / \mathrm{C} 6$ and $\mathrm{Gp}$ regions between AVNV and OsHV-1}

To compare the DNA sequences of the two viruses further, two fragments that were frequently used to detect OsHV-1 by PCR were analyzed and compared. The C2/C6 fragment contains polymorphisms that have been used to differentiate several OsHV-1 genotypes [27-29]. In this region, the DNA sequence of AVNV was $97 \%$ identical to that of OsHV-1, differing by three deletions, one insertion, and two substitutions (Figure 2). The major deletion consisted of five copies of a trinucleotide repeat (CTA) that was described previously as being a microsatellite region [29]. This trinucleotide was repeated three times in AVNV and eight times in OsHV-1 (Figure 2). Compared to OsHV-1, there were also two deletions of A residues in AVNV at positions 244 and 395 , an insertion of an A residue at position 283, and two synonymous substitutions in ORF4 at positions 411 and 516 (both $\mathrm{C}$ to $\mathrm{T}$ changes).
The Gp region encodes a putative glycoprotein (ORF88) and has been utilized to design primers for the detection and identification of OsHV-1 variants in French scallops [28]. The AVNV and OsHV-1 DNA sequences differed in this region by one synonymous and five non-synonymous substitutions (Table 1), yielding 99\% identity in this region at both the nucleotide and amino acid sequence levels. The five non-synonymous substitutions induced the modifications of ACC ( $\mathrm{T}$, threonine), GTG (V, valine), GCG (A, alanine), ATC (I, isoleucine) and GAA (E, glutamate) codons to AGC (S, serine), GCG (A, alanine), ACG ( $\mathrm{T}$, threonine), CTC (L, leucine) and GAC (D, aspartate) codons, respectively (Table 1 ).

\section{Discussion}

The complete genomic DNA sequences of AVNV isolated from Chinese scallops were determined using a PCR amplification strategy that has been used extensively to generate genome sequences for other viruses 


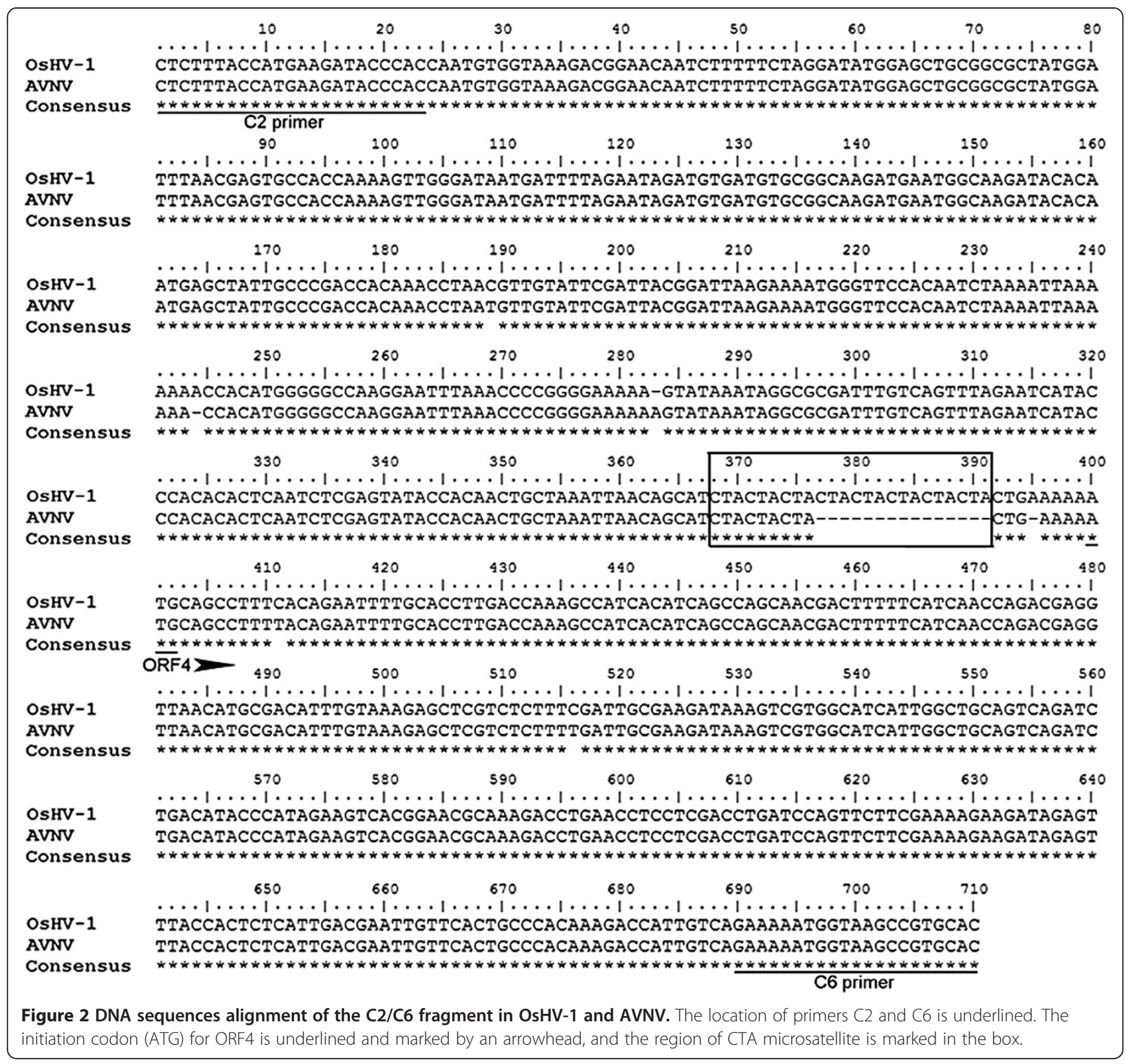

Table 1 Sequence variations in the Gp region (ORF88) between OsHV-1 and AVNV

\begin{tabular}{ccc}
\hline $\begin{array}{c}\text { Position } \\
\text { (bp) }\end{array}$ & $\begin{array}{c}\text { Nucleotide substitution } \\
\text { (OsHV-1 to AVNV) }\end{array}$ & $\begin{array}{c}\text { Amino acid substitution } \\
\text { (OsHV-1 to AVNV) }\end{array}$ \\
\hline 254 & $\mathrm{C} \rightarrow \mathrm{G}$ & $\mathrm{T} \rightarrow \mathrm{S}$ \\
1094 & $\mathrm{~T} \rightarrow \mathrm{C}$ & $\mathrm{V} \rightarrow \mathrm{A}$ \\
1821 & $\mathrm{~A} \rightarrow \mathrm{G}$ & $\mathrm{No}$ \\
1963 & $\mathrm{G} \rightarrow \mathrm{A}$ & $\mathrm{A} \rightarrow \mathrm{T}$ \\
1969 & $\mathrm{~A} \rightarrow \mathrm{C}$ & $\mathrm{H} \rightarrow \mathrm{L}$ \\
1995 & $\mathrm{~A} \rightarrow \mathrm{C}$ & $\mathrm{E} \rightarrow \mathrm{D}$ \\
\hline
\end{tabular}

[41-43]. The genome of AVNV was 210,993 bp in size, which was slightly longer than that of OsHV-1, and had a nucleotide composition of $38.5 \% \mathrm{G}+\mathrm{C}$, which is also similar to that of OsHV-1 (38.7\%) The genome organization consisted of three unique regions and two inverted repeat regions, which was similar as that of OsHV-1 [25] and also similar as that of herpes simplex virus [44] and human cytomegalovirus [45]. Comparative analysis of sequences revealed that AVNV was highly related, but not identical, to OsHV-1 at the nucleotide and amino acid sequence levels (97\% and 94-100\%, respectively). In addition, previous reports showed that the two viruses were also similar in epidemiology [36,46,47], morphology [25,33,34,48] and histopathology $[15,28,34,35]$. Based on these results, we propose that AVNV may be a variant of OsHV-1. 
Sequence comparisons have become the primary approach for evaluating phylogenetic and taxonomic relationships among herpesviruses and for identifying and assigning newly characterized viruses [40]. Using the C2/ C6 PCR primers, several OsHV-1 variants were described in France in clams [27], Pacific oysters and scallops [27,28]. This fragment contains a polymorphic microsatellite region consisting of a number of CTA repeats. AVNV has three repeats, whereas OsHV-1 has eight [25], the variant OsHV-1 $\mu$ Var has four [29], another OsHV-1 variant has six [49], and other French specimens present various numbers of CTA repeats [50]. These observations reinforce the fact that the microsatellite region does display polymorphisms and could be utilized for identifying and differentiating among OsHV-1 variants.

Generally, glycoproteins on the viral envelope bind to specific receptor molecules on the host cell, promoting viral entry into the host cell. For ORF88, encoding a putative glycoprotein [25,28], the modification of GTG (V, valine) to GCG (A, alanine) in AVNV was also reported in an OsHV-1 variant from French scallops by using the Gp3/ Gp4 PCR primers to amplify a part of the ORF [28]. It is possible that the polymorphisms in this region might reflect the host-specific, and this needs further investigation. Nevertheless, the fact that OsHV-1 has more than one host species is different to the situation for most vertebrate herpesviruses, which are thought to have coevolved or adapted in association with single host species, although exceptions have been described [40,51]. Upon successful transmission to new host species, viruses usually adapt quickly to the changed immunological environment [52]. One of the mechanisms of adaptation involves amino acid changes, in particular in proteins that may facilitate transmission [53]. Indeed, a number of proteins have been implicated in determining host specificity for various viruses [54]. For instance subtypes of influenza A virus may be distinguished by two surface glycoproteins, and amino acid substitutions may alter receptor binding to permit transmission from humans to birds $[55,56]$.

In comparison to OsHV-1, AVNV presents a large number of variations including deletions, insertions and substitutions in both coding and non-coding regions. One region located at 60,700-63,350 bp in AVNV is particularly unusual in bearing a large insertion of $2.6 \mathrm{~kb}$ compared to the OsHV-1 genome. Several OsHV-1 genotypes have also been described in oysters, scallops and clams based on analysis of various genome regions [27-29,50,57]. The finding that OsHV-1 specimens collected from different locations may have similar DNA sequences [50,57], whereas others collected from the same place showed different genotypes [29], suggests that particular genotypes may be not distributed geographically. More work on genome sequences analysis of different OsHV-1 genotypes would be useful in defining additionally diagnostic polymorphisms. Moreover, sequencing more OsHV-1 strains from different locations and host species may help to elucidate the biological and pathogenic associations of the various genotypes.

\section{Conclusions}

In this study, we have sequenced the AVNV genome sequence using a PCR-based approach. The AVNV genome is a linear, double-stranded DNA molecule of $210,993 \mathrm{bp}$ and its organization and ORFs layout are similar to that of OsHV-1. The DNA and amino acid sequences of AVNV are 97\% and 94-100\% identical to that of OsHV-1, respectively. Therefore, together with previous observations, our results suggest that AVNV could be a variant of OsHV-1.

\section{Materials and methods \\ Samples}

AVNV infected scallops, C. farreri, were collected from Qingdao, China, in 2007. All diseased animals showed clinical signs including slow reactions, weak water-spray, shrunken mantle, blemished ocelli and an enlarged digestive gland. Virus particles were observed in specimens by electron microscopy.

\section{Purification of virus and viral DNA}

Purification of virus particles was conducted as described by Wang et al. [33] and LeDeuff and Renault [48], with minor modifications. Seawater was filtered through $0.22 \mu \mathrm{m}$ membranes (Millipore, USA) and used in the following purification steps. Mantle, gill and kidney tissues from scallops were rinsed 3 times and homogenized in seawater (1:9) using an Ultra-Turrax tissue homogenizer. After centrifugation at 3,500 $\times \mathrm{g}$ and $7,500 \times \mathrm{g}$ for $15 \mathrm{~min}$ at $4^{\circ} \mathrm{C}$, the supernatant was overlaid onto a $30 \%(\mathrm{w} / \mathrm{v})$ sucrose solution and centrifuged at $125,000 \times \mathrm{g}$ for $1.5 \mathrm{~h}$ at $4^{\circ} \mathrm{C}$. The pellet was resuspended in seawater by mixing gently. The virus suspension was then layered on a $30-55 \%(\mathrm{w} / \mathrm{v})$ sucrose gradient and centrifuged at $125,000 \times \mathrm{g}$ for $3 \mathrm{~h}$ at $4^{\circ} \mathrm{C}$. The viral band was removed from the tube by side puncture, and AVNV DNA was extracted using a Takara MiniBEST DNA Extraction Kit Ver. 3.0 (Takara Bio Dalian Co. Ltd. Dalian, China) according to the manufacturer's protocol. The concentration of viral DNA was determined using a spectrophotometer.

\section{PCR amplification and DNA sequencing}

The AVNV genome sequence was determined using a PCR-based approach. As the sequences of OsHV-1 were highly similar in AVNV, a total of 62 PCR primer pairs were designed based on the OsHV-1 genome sequence (GenBank accession AY509253) and used to amplify 
overlapping AVNV DNA fragments (from 600 to $5000 \mathrm{bp})$. The AVNV genome termini were identified using the method described by Davison et al. [25,45]. Briefly, AVNV DNA was treated with T4 DNA polymerase in the presence of the four dNTPs to produce flush ends, and ligated into the partially double-stranded adaptor (the cDNA adaptor in the Clontech Marathon kit). PCR was carried out using an adaptor-specific primer plus a primer specific for the left or right terminal region of the genome (5'-CACGGTGGGAAGGCTGAT3' or 5'-GATAGGAGGTTAGACACGC-3' and Ex Taq polymerase (Takara). The products were purified using a TaKaRa gel purification kit (Takara), and inserted into pGEM-T (Promega, USA). The cloned fragments were sequenced in both directions using universal primers and an ABI PRISM 3770 (Applied Biosystems, Inc., USA). Additional primers (236 in total) were designed for sequencing the internal regions of longer PCR products $(>1200 \mathrm{bp})$. At least three individual clones were sequenced for each fragment in order to exclude potential mutations generated by PCR.

\section{Computer-assisted analysis of DNA sequence data}

Genomic composition and structure were analyzed using DNASTAR (Lasergene). The location and amino acid sequences of ORFs were predicted using Accelrys Gene 2.5 (Accelrys Inc.) and NCBI ORF finder (http://www. ncbi.nlm.nih.gov/gorf/gorf.html) according to the following criteria: (1) they were $\geq 120 \mathrm{bp}$ in size, (2) they were not located within larger ORFs, (3) polyadenylation signal were analyzed and (4) they were compared with other sequences using NCBI BLASTP (http://www.ncbi. nlm.nih.gov/). Dot matrix comparisons of DNA sequences were carried out using Accelrys Gene 2.5. Complete genome sequence alignments were performed using Geneious (Biomatters Ltd, New Zealand).

\section{Nucleotide sequence accession number}

The complete genome sequence of AVNV reported in this paper has been released in the GenBank database under accession number GQ153938.

\section{Additional file}

Additional file 1: Table S1. Potential open reading frames of the AVNV genome.

\section{Abbreviations}

AVNV: Acute viral necrosis virus; OsHV-1: Ostreid herpesvirus 1; ORF: Open reading frame; GP: Glycoprotein; bp: Base pair; kb: Kilobase pair; PCR: Polymerase chain reaction.

\section{Competing interests}

The authors declare that they have no competing interests.

\section{Authors' contributions}

WR and CW conceived the study and wrote the manuscript; YC participated in sample collection; TR, JH and HC participated in the discussion and modification of the manuscript; WR carried out the experiments and data analysis. HC and CB participated in the re-analysis of data when revised the manuscript. All authors have read and approved the manuscript.

\section{Acknowledgements}

The authors would like to thank the reviewers for their comments that help improve the manuscript. This study was supported by grants from the national High Technology Research and Development Program of China (Project No. 2006AA100307) and the China Agriculture Research System (Project No.CARS-48)

\section{Author details}

Maricultural Organism Disease Control and Pathogenic Molecular Biology Laboratory, Yellow Sea Fisheries Research Institute, Chinese Academy of Fishery Science, Qingdao 266071, China. ${ }^{2}$ Department of Rheumatology and Inflammation, University of Gothenburg, Gothenburg 40530, Sweden. ${ }^{3}$ Department of Biological and Environmental Sciences, University of Gothenburg, Gothenburg 40530, Sweden. ${ }^{4}$ Ifremer, Unité Santé, Génétique et Microgiologie des Mollusques, Laboratoire de Génétique et Pathologie des Mollusques Marins, 17390, La Tremblade, France.

Received: 30 June 2012 Accepted: 28 March 2013

Published: 8 April 2013

\section{References}

1. Comps M, Bonami JR: Infection virale associée à des mortalités chez I'huître Crassostrea angulata. Th C r Acad Sci D 1997, 285:1139-1140.

2. Comps M, Duthoit JL: Infection virale associé à la maladie des branchies de l'huître portugaise portugaise Crassostrea angulata Lmk. C R Acad SC Hebd Seances Acad Sci D 1996, 283:1595-1597.

3. Farley CA, Banfield W, Kasnic G, Foster WS: Oyster herpes-type virus. Sciense 1972, 178:759-760.

4. Farley CA: Proliferative disorders in bivalve molluscs. Mar Fish Rev 1976, 38:30-33.

5. Farley CA: Viruses and virus-like lesions in marine molluscs. Mar Fish Rev 1978, 40:18-20.

6. Ramussen LPD: Occurrence, prevalence and seasonality of neoplasia in the marine mussel Mytilus edulis from three sites in Denmark. Mar Biol 1986, 92:59-64.

7. Miyazaki T, Goto K, Kobayashi T, Kageyama T, Miyata M: Mass mortalities associated with a virus disease in Japanese pearl oysters Pinctada fucata martensii. Dis Aquat Org 1999, 37:1-12.

8. Bower SM: Synopsis of infectious diseases and parasites of commercially exploited shellfish: Assorted viruses detected in oysters and of unknown significance. 2001. http://www-sci.pac.dfo-mpo.gc.ca/shelldis/assortvirusoy_e. htm.

9. Renault T, Novoa B: Viral infection among bivalves. Aquat Living Res 2004, 17:397-409.

10. Oprandry JJ, Chang PW, Pronovost AD, Cooper KR, Brown CW, Yates VJ: Isolation of a viral agent causing hematopoietic neoplasia in the softshell clam, Mya arenaria. J Invertebr Pathol 1981, 38:45-51.

11. King AMQ, Adams MJ, Carstens EB, Lefkowitz EJ: Virus taxonomy: classification and nomenclature of viruses: Ninth Report of the International Committee on Taxonomy of Viruses. San Diego: Elsevier Academic Press; 2012

12. Hine PM, Wesney B, Hay BE: Herpesvirus associated with mortalities among hatchery-reared larval Pacific oysters Crassostrea gigas. Dis Aquat Org 1992, 12:135-142.

13. Nicolas JL, Comps M, Cochennec N: Herpes-like virus infecting Pacificoyster larvae, Crassostrea gigas. Bull Eur Assoc Fish Pathol 1992, 12:11-13.

14. Comps M, Cochennec N: A herpes-like virus from the European oyster Ostrea edulis L. J Invertebr Pathol 1993, 62:201-203.

15. Renault T, Le Deuff RM, Cochennec N, Maffart P: Herpesviruses associated with mortalities among Pacific oyster, Crassostrea gigas, in Francecomparative study. Rev Med Vet 1994, 145:735-742.

16. Hine PM, Thorne T: Replication of herpes-like viruses in haemocytes of adult flat oysters Ostrea angasi: an ultrastructural study. Dis Aquat Org 1997, 29:189-196. 
17. Hine PM, Wesney B, Besant P: Replication of a herpes-like virus in larvae of the flat oyster Tiostrea chilensis at ambient temperatures. Dis Aquat Org 1998, 32:161-171.

18. Vásquez-Yeomans R, Cáceres-Martínez J, Huerta AF: Herpes-like virus associated with eroded gills of the Pacific oyster Crassostrea gigas in Mexico. J Shellfish Res 2004, 23:417-419.

19. Friedman CS, Estes RM, Stokes NA, Burge CA, Hargove JS, Barber BJ, Elston RA, Burreson EM, Reece KS: Herpes virus in juvenile Pacific oysters Crassostrea gigas from Tomales Bay, California, coincides with summer mortality episodes. Dis Aquat Org 2005, 63:33-41.

20. Chang PH, Kuo ST, Lai SH, Yang HS, Ting YY, Hsu CL, Chen HC: Herpes-like virus infection causing mortality of cultured abalone Haliotis diversicolor supertexta in Taiwan. Dis Aquat Org 2005, 65:23-27.

21. Hooper C, Hardy-Smith P, Handlinger J: Ganglioneuritis causing high mortalities in farmed Australian abalone (Haliotis laevigata and Haliotis rubra). Australian Vet J 2007, 85:188-193.

22. Tan J, Lancaster M, Hyatt A, van Driel R, Wong F, Warner S: Purification of a herpes-like virus from abalone (Haliotis spp) with ganglioneuritis and detection by transmission electron microscopy. J Virol Methods 2008 149:338-341.

23. Renault T, Le Deuff RM, Chollet B, Cochennec N, Gérard A: Concomitant herpes-like virus infections in hatchery-reared larvae and nurserycultured spat Crassostrea gigas and Ostrea edulis. Dis Aquat Org 2000, 42:173-183.

24. Renault T, Lipart C, Arzul I: A herpes-like virus infects a non-ostreid bivalve species: virus replication in Ruditapes philippinarum larvae. Dis Aquat Org 2001, 45:1-7.

25. Davison AJ, Trus BL, Cheng N, Steven AC, Watson MS, Cunningham C, Le Deuff RM, Renault T: A novel class of herpesvirus with bivalve hosts. $J$ Gen Virol 2005, 86:41-53.

26. Renault T, Lipart C, Arzul I: A herpes-like virus infecting Crassostrea gigas and Ruditapes philippinarum larvae in France. J Fish Dis 2001, 24:369-376.

27. Arzul I, Renault T, Lipart C, Davison AJ: Evidence for interspecies transmission of oyster herpesvirus in marine bivalves. J Gen Virol 2001 82:865-870

28. Arzul I, Nicolas JL, Davison AJ, Renault T: French scallops: a new host for ostreid herpesvirus-1. Virol 2001, 290:342-349.

29. Segarra A, Pépin JF, Arzul I, Morga B, Faury N, Renault T: Detection and description of a particular Ostreid herpesvirus 1 genotype associated with massive mortality outbreaks of Pacific oysters Crassostrea gigas in France in 2008. Virus Res 2010, 153:92-99.

30. Yu RH, Wang RC, Tian CY, Wang ZP: Discussion on the high mortality and its prevention in scallop Chlamys farreri. Trans Oceanol Limnol 1998, 71:69-72.

31. Guo XM, Ford SE, Zhang FS: Molluscan aquaculture in China. J Shellfish Res 1999, 18:19-31.

32. Song $W B$, Wang $C M$, Wang $X H$, Li Y: New research progress on massive mortality of cultured scallop Chlamys farreri. Mar Sci 2001, 25:23-27.

33. Wang $\mathrm{CM}$, Wang $\mathrm{XH}$, Song $\mathrm{XL}$, Huang J, Song WB: Purification and ultrastructure of a spherical virus in cultured scallop Chlamys farreri. $J$ Fish China 2002, 26:180-184.

34. Liu YJ, Wu XZ, Zhu MZ, Wang C, Zhang QZ, Pan JP: Ultrastructural observation and cytopathology of spherical virus in Chlamys farreri (Jones and Preston). J Tropical Oceanography 2002, 21:76-79.

35. Fu C, Song W, Li Y: Monoclonal antibodies developed for detection of an epizootic virus associated with mass mortalities of cultured scallop Chlamys farreri. Dis Aquat Organ 2005, 65:17-22.

36. Wang XH, Wang CM, Li J, Wang XH, Zheng GL, Hu XZ, Gong J, Song WB: Epidemiological study on massive death of the cultured scallop Chlamys farreri in the Jiaozhou Bay. J Fish China 2002, 26:149-155.

37. Stow ND, McMonagle EC: Characterization of the $T R_{S} / R_{S}$ origin of DNA replication of herpes simplex virus type 1. Virol 1983, 130:427-438

38. Weller SK, Spadaro A, Schaffer JE, Murray AW, Maxam AM, Schaffer PA: Cloning sequencing and functional analysis of oriL a herpes simplex virus type 1 origin of DNA synthesis. Mol Cell Biol 1985, 5:930-942.

39. Inoue N, Dambaugh TR, Rapp JC, Pellett PE: Alphaherpesvirus originbinding protein homolog encoded by human herpesvirus $6 \mathrm{~B}$ a betaherpesvirus binds to nucleotide sequences that are similar to ori regions of alphaherpesviruses. J Virol 1994, 68:4126-4136.

40. McGeoch DJ, Rixon FJ, Davison AJ: Topics in herpesvirus genomics and evolution. Virus Res 2006, 117:90-104
41. Do JW, Moon CH, Kim HJ, Ko MS, Kim SB, Son JH, Kim JS, An EJ, Kim MK, Lee SK, Han MS, Cha SJ, Park M, Park MA, Kim YC, Kim JW, Park JW: Complete genomic DNA sequence of rock bream iridovirus. Virol 2004, 325:351-363.

42. Zhou SY, Chen C, Weng SP, Chan SM, He JG, Lü L: Complete genome sequence analysis of an iridovirus isolated from the orange-spotted grouper Epinephelus coioides. Virol 2005, 339:81-100.

43. Shi CY, Jia KT, Yang B, Huang J: Complete genome sequence of a Megalocytivirus (family Iridoviridae) associated with turbot mortality in China. Virol J 2010, 7:159.

44. McGeoch DJ, Dalrymple MA, Davison AJ, Dolan A, Frame MC, McNab D, Perry $\amalg$, Scott JE, Taylor P: The complete DNA sequence of the long unique region in the genome of herpes simplex virus type 1. J Gen Virol 1998, 69:1531-1574.

45. Davison AJ, Dolan A, Akter P, Addison C, Dargan DJ, Alcendor DJ, McGeoch DJ, Hayward GS: The human cytomegalovirus genome revisited: comparison with the chimpanzee cytomegalovirus genome. J Gen Virol 2003, 84:17-22.

46. Renault T, Le Deuff RM, Cochennec N, Chollet B, Maffart P: Herpesviruses associated with high mortality levels in larvae and spat of Pacific oysters Crassostrea gigas: a comparative study the thermal effects on virus detection in hatchery-reared larvae reproduction of the disease in axenic larvae. Vet Res 1995, 26:539-543.

47. Le Deuff RM, Renault T, Gerard A: Effects of temperature on herpes-like virus detection among hatchery-reared larval Pacific oyster Crassostrea gigas. Dis Aquat Org 1996, 24:149-157.

48. Le Deuff RM, Renault T: Purification and partial genome characterization of a herpes-like virus infecting the Japanese oyster Crassostrea gigas. J Gen Virol 1999, 80:1317-1322.

49. Martenot $C$, Oden $E$, Travaillé E, Malas JP, Houssin M: Detection of different variants of Ostreid Herpesvirus 1 in the Pacific oyster Crassostrea gigas between 2008 and 2010. Virus Res 2011, 160:25-31.

50. Renault T, Moreau P, Faury N, Pepin JF, Segarra A, Webb S: Analysis of clinical ostreid herpesvirus 1 (Malacoherpesviridae) specimens by sequencing amplified fragments from three virus genome areas. J Virol 2012, 86:5942-7.

51. Walzek TB, Kelley GO, Alfaro ME, Kurobe T, Davison AJ, Hedrick RP: Phylogenetic relationships in the family Alloherpesviridae. Dis Aquat Organ 2009, 84:179-194.

52. Webby R, Hoffmann E, Webster R: Molecular constraints to interspecies transmission of viral pathogens. Nat Med 2004, 10:S77-S81.

53. Qu XX, Hao P, Song XJ, Jiang SM, Liu YX, Wang PG, Rao X, Song HD, Wang SY, Zuo Y, Zheng AH, Luo M, Wang HL, Deng F, Wang HZ, Hu ZH, Ding MX, Zhao GP, Deng HK: Identification of two critical amino acidresidues of the severe acute respiratory syndrome coronavirus spike protein for this variation in zoonotic tropism transition via a double substitution strategy. J Biol Chem 2005, 280:29588-29595.

54. Bandin I, Dopazo C: Host range host specificity and hypothesized host shift events among viruses of lower vertebrates. Vet Res 2011, 42:67-81.

55. Connor RJ, Kawaoka Y, Webster RG, Paulson JC: Receptor specificity in human avian and equine $\mathrm{H} 2$ and H3 Influenza virus isolates. Virol 1994, 205:17-23.

56. Matrosovich M, Tuzikov A, Bovin N, Gamabaryan A, Klimov A, Castrucci MR, Donatelli I, Kawaoka Y: Early alterations of the receptor-binding properties of $\mathrm{H} 1 \mathrm{H} 2$ and $\mathrm{H} 3$ avian influenza virus hemagglutinins after their introduction into mammals. J Virol 2000, 74:8502-8512.

57. Moss JA, Burreson EM, Cordes JF, Dungan CF, Brown GD, Wang A, Wu X, Reece KS: Pathogens in Crassostrea ariakensis and other Asian oyster species: implications for non-native oyster introduction to Chesapeake Bay. Dis Aquat Org 2007, 77:207-223.

doi:10.1186/1743-422X-10-110

Cite this article as: Ren et al:: Complete genome sequence of acute viral necrosis virus associated with massive mortality outbreaks in the Chinese scallop, Chlamys farreri. Virology Journal 2013 10:110. 